www.jmscr.igmpublication.org

Impact Factor 5.244

Index Copernicus Value: 5.88 ISSN (e)-2347-176x ISSN (p) 2455-0450 crossref DOI:_http://dx.doi.org/10.18535/jmscr/v4i4.15

Journal Of Medical Science And Clinical Research

\title{
Spectrum of Biopsy Proven Renal Diseases (BPRD): A Single Center
} Experience

(Original article)

Authors:

\section{Lakshminarayana GR ${ }^{1}$, Indu $\mathrm{S}^{2}$, Seethalekshmy $\mathrm{NV}^{3}$, Ranjit $\mathrm{N}^{4}$, Biju $\mathrm{MV}^{5}$}

${ }^{1}$ Consultant Nephrologist, Department of Nephrology, EMS Memorial Cooperative Hospital and Research

Centre, Perinthalmanna, Malappuram, Kerala, India

${ }^{2}$ Physician Assistant, Department of Nephrology, EMS Memorial Cooperative Hospital and Research

Centre, Perinthalmanna, Malappuram, Kerala, India

${ }^{3}$ Professor, Department of Pathology, Amrita Institute of Medical Sciences and Research Centre, Kochi, Kerala, India

${ }^{4}$ Assistant Professor, Department of Nephrology, KMCT Medical College, Manassery PO, Mukkam,

Kozhikode, Kerala, India

${ }^{5}$ Consultant Nephrologist, Department of Nephrology, DM Waynad Institute of Medical Sciences, Meppadi,

Waynad, Kerala, India

Corresponding author:

\section{Dr Lakshminarayana GR,}

Consultant Nephrologist, Department of Nephrology, EMS Memorial Cooperative Hospital and Research

Centre, Perinthalmanna, Malappuram, Kerala, India-679322

Email:drlng23@gmail.com, Phone: (+91)9495161833

\begin{abstract}
Kidney biopsy is one of the most important tools in the assessment of kidney disease as histopathological diagnosis promotes evidence based practice in Nephrology. This is a study was done by including all consecutive percutaneous kidney biopsies (273; Males:147, Females: 126) performed at EMS Memorial Cooperative Hospital, Perinthalmanna, Kerala, India, from September 2009 to February 2016. Among the biopsy proven renal diseases (BPRD); primary glomerular diseases (PGD) were the commonest (78.39\%) followed by secondary glomerular diseases (SGD) (12.45\%) and tubulointerstitial diseases (TID) (9.16\%). The IgA Nephropathy (IgAN) was the commonest PGD and majority had mesangial hypercellularity (M1) (93.54\%), tubular atrophy (T1 or T2 67.74\%) and the most common pattern was M1, E0, SO, T1, suggesting that patients of Indian subcontinent have aggressive disease type; unlike western literature. The focal segmental glomerulosclerosis (FSGS) was the second commonest PGD and majority were of not otherwise specified (NOS) type. FSGS, membranous nephropathy $(M N)$ and minimal change disease (MCD) were the 3 most common causes for PGD causing nephrotic syndrome. Diabetic nephropathy and lupus nephritis (LN) were the two most common biopsy proven SGD. Among the patients of diabetes mellitus (DM) who underwent renal biopsy with suspicion of non-diabetic renal disease (NDRD); 58.33\% had NDRD, 16.67\% had DN+ NDRD and 25\% had DN alone. This study the changing pattern BPRD in comparison to earlier studies. This study also, confirms the aggressive nature of IgAN in Indian patients and underlines the importance of renal biopsy in patients of DM.

Key Words: Renal biopsy, primary glomerular diseases, secondary glomerular diseases, Oxford-MEST classification,
\end{abstract}




\section{INTRODUCTION}

Kidney biopsy is one of the most important tools in the assessment of kidney disease as histopathological diagnosis promotes evidence based practice in Nephrology. Kidney biopsy is safe procedure which helps to reach the correct diagnosis andto use of treatment based on histopathologic diagnosis and predict the clinical course and outcome. ${ }^{[1-8]}$ The pattern of biopsy proven renal disease (BPRD) varies based geographic area and also changes with time. ${ }^{[2-8]}$ There is limited data regarding BPRD, as there is no renal biopsy registry India.This study was conducted to analyze the histopathologic pattern of renal of renal biopsies from a tertiary care centre in south India.

\section{AIMS AND OBJECTIVES}

- To classify the BPRD based on histopathology in different age groups

- To analyze the difference in pattern of BPRD based on gender and age groups.

\section{MATERIALS AND METHODS}

This is a retrospective study of all consecutive percutaneous kidney biopsies performed at EMS Memorial Cooperative Hospital and Research Centre, Perinthalmanna, Kerala, from September 2009 to February 2016. All the biopsies were performed under ultrasound guidance usingBard ${ }^{\circledR}$ Max-Core ${ }^{\circledR}$ disposable core biopsy instrument, CR Bard Inc., USA.All the biopsies were analyzed by light microscopy using hematoxylin and eosin, periodic acid Schiff, Jone's silver methaneamine and Gomori's trichrome stains and immunofluorescence studies were performed using anti-human IgG, IgA, IgM, C3, C1q, kappa and lambda light chains. Electron microscopy was done in few cases.

The indications of renal biopsies in the study were;steroid dependant or resistant nephrotic syndrome (SDNS or SRNS), adult onset nephrotic syndrome, unexplained renal failure, rapidly progressive renal failure (RPRF), acute nephritic syndrome (ANS) with features suggesting diagnosis other than PIGN (post infective glomerulonephritis), renal involvement in systemic disease, familial renal disease, asymptomatic urinary abnormality (proteinuria $>1 \mathrm{~g} /$ day and or haematuria) and diabetes mellitus with features suggestive of nondiabetic renal disease.

Statistical analysis was done using SPSS 17 for Windows, by SPSS Inc. IL, USA. The quantitative variables (age) have been described as mean $\pm \mathrm{SD}$ and range. The prevalence of biopsy proven renal disorders was summarized as counts and percentages. A Chi-square test was used to assess the trends in the prevalence of BPRD, among gender categories.

\section{RESULTS}

A total of 273 (Males:146, Females: 127) subjects, aged from 7-80 years (Mean:40.89, SD: 15.75) who underwent renal biopsies, were included in the study (Table 1), 1 patient was excluded because of inadequate sample. Both males and females were of similar age (Table 1); the difference was statistically insignificant (p:0.076). Among the BPRD; primary glomerular diseases (Table 1: 78.39\%) were the commonest followed by secondary glomerular diseases (Table 4: 12.45 $\%$ ) and tubulointerstitial diseases (Table 5: 9.16\%).

\section{Primary glomerular diseases (PGD)}

Ig A nephropathy(IgAN)(22.71\%) was the most common of the biopsy proven PGD, followed by FSGS (13.55\%), DPGN (10.99\%), MN (7.69\%), MCD (7.69\%), CGN (4.03\%),Pauci-immune crescentic GN (ANCA positive) (2.93\%), MesPGN (2.56\%), IgMN (1.46\%), non-amyloid deposition disease (1.10\%), MPGN (type 1) (1.10\%), Anti GBM antibody disease (1.1\%), Amyloidosis (primary) (0.70\%)FPGN (0.40\%), and C3 Glomerulopathy (0.40\%) (Table 2).

\section{Ig A Nephropathy}

The IgAN was the most common $(22.71 \%, 62$ out of 273) of PGD, in our study (Table 1). The mean age of the patients was 38.08 years and male: female ratio was $1.48: 1$. The $\operatorname{IgAN}$ was classified 
according to the Oxford-MEST classification [mesangial hypercellularity score $(\mathrm{M} ; \mathrm{M} 0 \leq 0.5$, M1 >0.5), the presence of endocapillary proliferation (E; E0: absent, E1: present) and segmental glomerulosclerosis/adhesion (S; S0: absent, S1: present), and the severity of tubular atrophy/interstitial fibrosis (T; T0 $\leq 25 \%, \mathrm{~T} 1: 26-$ $50 \%, \mathrm{~T} 2>50 \%$ ]. Majority of the patients had mesangial hypercellularity $(93.54 \%, 58$ patients) and tubular atrophy $(67.74 \%, 40 ; \mathrm{T} 1-43.55 \%$ or 26, T2-24.19\% or 14 patients) (Table 3, Figure 1). Only few patients had endocapillary proliferation $(18.33 \%, 11)$, and segmental sclerosis $(45 \%, 25)$ (Table 5, Figure 2). Glomerular crescents (involving 5-20\% of glomeruli) were found in $10 \%$ (6 patients, 5 fibrocellular, 1 cellular) of patients with $\operatorname{IgAN}$. The most common type of IgAN as per Oxford-MEST classification in the study was M1, E0, S0, T1 (20.97\%, 13 out of 62) and the least common type was M0, E0, S0, T0 (4.84\%, 3 out of 62$) .3$ patients with IgAN had purpuric skin lesions and were diagnosed as Henoch Schonlein purpura.

\section{Focal segmental glomerulosclerosis (FSGS)}

The FSGS was the second $(13.55 \%, 37$ out of 273) commonest of PGD in the study. The mean age of the patients was 36.72 years and male: female ratio of 1.64:1. In majority of the patients with FSGS; it was NOS (not-otherwise specified) type $(94.59 \%, 35)$, followed by tip $(2.7 \%, 1)$ and perhilar variants $(2.7 \%, 1$ patient). None of the patients in our study had collapsing or cellular variant FSGS.

\section{Diffuse proliferating glomerulonephritis (DPGN)}

The DPGN was the third $(10.99 \%, 30$ out of 273$)$ commonestof PGD in the study. The mean age of the patients was 43.63 years and male: female ratio of 1:1. All the patients had low $\mathrm{C} 3$ and 4 patients low $\mathrm{C} 4$, morphologically it was suggestive of post-infective glomerulonephritis.

\section{Membranous nephropathy (MN)}

The MN was the fourth $(7.69 \%, 21$ out of 273) commonestof PGD in the study. The mean age of the patients was 50.90 years and male: female ratio of 1.1:1. In all the patients it was morphologically suggestive of primary $\mathrm{MN}$, however, anti PLA2R antibody antibodies were not estimated.

\section{Minimal change disease (MCD)}

The MCD was the fourth $(7.69 \%, 21$ out of 273$)$ commonest of PGD along with MN in the study. The mean age of the patients was 30.14 years and male: female ratio of $0.9: 1$. Six out 21 patients were aged 12-15 years (Mean:13.33) and were biopsied for SDNS, and others were aged from 23-65 years (Mean:36.87) and biopsied for adult onset nephrotic syndrome.

\section{Secondary glomerular diseases (SGD)}

Diabetic nephropathy (5.49\%) was the most common, biopsy proven SGD, followed by LN (5.13\%), postpartum HUS, Alport's disease, MPGN (Cryoglobulinemia),LCDD and Membranous nephropathy (Hepatitis B infection) (Table 4).

\section{Diabetic nephropathy $(\mathrm{DN})$}

The DN was the commonest SGD $9.16 \%$ (25 out of 273$) ; 5.49 \%(15 / 273)$, having $\mathrm{DN}$ alone and $3.67 \%$ (10/273) having DN in association with non-diabetic renal disease (NDRD).The mean age in patients with DN alone was 52.2 yearsand male: female ratio was 2:1. The commonest NDRD to be associated with DN was acute tubular necrosis (ATN) $(6.67 \%, 4)$ followed by DPGN $(1.67 \%, 1), \operatorname{IgAN}(1.67 \%, 1)$, anti GBM antibody disease $(1.67 \%, 1)$, pauci-immune crescentic GN $(1.67 \%, 1), \mathrm{CGN} \quad(1.67 \%, 1)$ andCTIN $(1.67 \%, 1)$. The number in brackets representing percentages and the number of patients among 60 with DM who underwent renal biopsy.The patients with NDRD were included in respective categories of based on histological diagnosis.

\section{Lupus nephritis (LN)}

The LN was second commonest $(5.13 \%, 14$ out of 273) SGD. The mean age in patients with $L N$ was 26.14 years (Range: 11-39) and all were females. The LN was classified as per ISN/RPS (International Society of Nephrology and Renal Pathology Society) 2004 classification. The class 
IV G-A was most common type (42.85\%, 6 out of 14) followed by class III A $(21.43 \%, 3)$, class IV $\mathrm{A} / \mathrm{C}(14.28 \%, 2)$, class $\mathrm{IV}+\mathrm{V}(14.28 \%, 2)$ and class III A/C (7.14\%, 1 patient).

\section{Miscellaneous secondary glomerular diseases}

The rarer secondary glomerular diseases included postpartum HUS, Alport's disease, MPGN (Cryoglobulinemia) LCDD (Multiple Myeloma) and Membranous nephropathy (HBV infection). The patient with Alport's disease was confirmed by electron microscopy.

\section{Tubulointerstitial diseases (TID)}

ATN (3.66\%) was themost common, biopsy proven TID followed by, CTIN (2.56\%) Cast nephropathy (1.5\%), AIN (1.1\%), ACN (0.4\%) (Table 5).

\section{BPRD in patients with Diabetes mellitus (DM)}

A total 60 patients (Males:39, Females:21, Mean age: 52.53 years) of DM underwent renal biopsy; with a suspicion of non-diabetic renal disease. The indications for renal biopsy were: nephrotic range proteinuria without progression through microalbuminuria, macroscopic haematuria, red cell casts, sterile pyuria, acute on chronic renal failure, absence of diabetic retinopathy, nephrotic range protienuria with duration of $\mathrm{DM}<5$ years. The nondiabetic renal disease (NDRD) was found in $58.33 \%$ of those with diabetic mellitus, diabetic nephropathy with superimposed nondiabetic renal diseasein $16.67 \%$ and $25.00 \%$ had diabetic nephropathy (DN) alone in renal biopsy (Table 6, Figure 2). The mean duration of diabetes mellitus was $10,9,33$ and 6.83 years in patients with DN, DN+NDRD and NDRD, respectively.

The most common nondiabetic renal disease was Ig A nephropathy $(11.67 \%, 7)$ followed by DPGN $(8.33 \%, 5), \mathrm{MN}(6.67 \%, 4), \mathrm{FSGS}(5 \%, 3)$, CGN $(3.33 \%, 2)$, MPGN $(3.33 \%, 2)$, primary amyloidosis $(3.33 \%, 2)$, CTIN $(3.33 \%, 2)$, AIN $(3.33 \%, 2), \operatorname{MCD}(1.67 \%, 1), \operatorname{IgM}$ nephropathy $(1.67 \%, 1)$, pauci-immune crescentic GN $(1.67 \%$, $1)$, anti GBM antibody disease $(1.67 \%, 1)$, nonamyloid deposition disease $(1.67 \%, 1)$ and cast nephropathy (1.67\%, 1 patient) (Figure 3$)$. The number in brackets representing percentages and the number of patients; among 60 with DM who underwent renal biopsy.

\begin{tabular}{|c|c|c|c|c|c|c|c|c|}
\hline \multirow[b]{2}{*}{ Gender } & \multirow[b]{2}{*}{$\mathbf{N}$} & \multirow[b]{2}{*}{ Mean } & \multirow[b]{2}{*}{ Std. Deviation } & \multirow[b]{2}{*}{ Std. Error } & \multicolumn{2}{|c|}{$\begin{array}{l}95 \% \text { Confidence Interval for } \\
\text { Mean }\end{array}$} & \multirow[b]{2}{*}{ Minimum } & \multirow[b]{2}{*}{ Maximum } \\
\hline & & & & & Lower Bound & Upper Bound & & \\
\hline Females & 127 & 39.08 & 16.582 & 1.471 & 36.17 & 41.99 & 7 & 80 \\
\hline Males & 146 & 42.47 & 14.867 & 1.230 & 40.04 & 44.90 & 8 & 76 \\
\hline Total & 273 & 40.89 & 15.751 & 0.953 & 39.02 & 42.77 & 7 & 80 \\
\hline
\end{tabular}


Table 2: Primary glomerular diseases (PGD)

\begin{tabular}{|c|c|c|c|c|c|c|c|c|}
\hline Renal disease & $\begin{array}{l}\text { Patients } \\
(\text { (n \& \%) }\end{array}$ & $\begin{array}{l}\text { HTN } \\
(\mathrm{n} \& \\
\%)\end{array}$ & $\begin{array}{l}\text { Nephrotic } \\
\text { syndrome } \\
(\text { n \& \%) }\end{array}$ & $\begin{array}{l}\text { Renal } \\
\text { failure } \\
(\text { n \& \%) }\end{array}$ & $\begin{array}{l}\text { Males } \\
\text { (n) }\end{array}$ & $\begin{array}{l}\text { Females } \\
\text { (n) }\end{array}$ & $\begin{array}{l}\text { Age in years } \\
\text { (Mean\& } \\
\text { Range) } \\
\end{array}$ & $\begin{array}{l}\text { p-value } \\
(\mathrm{M} \& \mathrm{~F})\end{array}$ \\
\hline Ig A Nephropathy (IgAN) & $62(22.71)$ & $\begin{array}{l}29 \\
(46.77)\end{array}$ & $4(6.45)$ & $38(61.29)$ & 37 & 25 & $\begin{array}{l}38.08 \\
(12-75) \\
\end{array}$ & 0.42 \\
\hline $\begin{array}{ll}\text { Focal } & \text { Segmental } \\
\text { Glomerulosclerosis (FSGS) }\end{array}$ & $37(13.55)$ & $\begin{array}{l}22 \\
(59.46)\end{array}$ & $29(78.38)$ & $14(37.84)$ & 23 & 14 & $\begin{array}{l}36.73 \\
(17-69)\end{array}$ & 0.36 \\
\hline $\begin{array}{l}\text { Diffuse proliferative } \\
\text { Glomerulonephritis (DPGN) }\end{array}$ & $30(10.99)$ & $\begin{array}{l}13 \\
(43.33)\end{array}$ & $6(20)$ & $25(83.33)$ & 15 & 15 & $\begin{array}{l}43.63 \\
(8-70)\end{array}$ & 0.51 \\
\hline $\begin{array}{l}\text { Membranous nephropathy } \\
\text { (MN) }\end{array}$ & $\begin{array}{l}21 \\
(7.69)\end{array}$ & $\begin{array}{l}9 \\
(42.86)\end{array}$ & $15(71.43)$ & $4(19.05)$ & 11 & 10 & $\begin{array}{l}50.90 \\
(23-80)\end{array}$ & 0.78 \\
\hline $\begin{array}{l}\text { Minimal change } \\
\text { (MCD) }\end{array}$ & $\begin{array}{l}21 \\
(7.69)\end{array}$ & $2(9.5)$ & $18(85.71)$ & 0 & 10 & 11 & $\begin{array}{l}30.14 \\
(12-65)\end{array}$ & 0.46 \\
\hline $\begin{array}{l}\text { Chronic Glomerulonephritis } \\
\text { (CGN) }\end{array}$ & $\begin{array}{l}11 \\
(4.03)\end{array}$ & $\begin{array}{l}8 \\
(72.73)\end{array}$ & $1(9.09)$ & $11(100)$ & 8 & 3 & $\begin{array}{l}46.36 \\
(30-61)\end{array}$ & 0.22 \\
\hline Pauci-immune crescentic GN & $\begin{array}{l}8 \\
(2.93)\end{array}$ & $\begin{array}{l}1 \\
(12.5)\end{array}$ & 0 & $8(100)$ & 3 & 5 & $\begin{array}{l}43.87 \\
(23-65)\end{array}$ & 0.31 \\
\hline $\begin{array}{l}\text { Mesangioproliferative } \\
\text { (MesPGN) }\end{array}$ & $\begin{array}{l}7 \\
(2.56)\end{array}$ & $\begin{array}{l}5 \\
(71.42)\end{array}$ & $2(28.57)$ & $2(28.57)$ & 1 & 6 & $\begin{array}{l}36.14 \\
(23-46)\end{array}$ & 0.02 \\
\hline IgM Nephropathy (IGMN) & $\begin{array}{l}4 \\
(1.46)\end{array}$ & $\begin{array}{l}1 \\
(25)\end{array}$ & $3(75)$ & 0 & 1 & 3 & $\begin{array}{l}22.24 \\
(14-29)\end{array}$ & 0.22 \\
\hline $\begin{array}{ll}\text { Non-amyloid } & \text { deposition } \\
\text { disease (NADD) } & \\
\end{array}$ & $\begin{array}{l}3 \\
(1.10)\end{array}$ & 0 & $1(50)$ & 0 & 2 & 1 & $\begin{array}{l}47.33 \\
(36-58) \\
\end{array}$ & 0.68 \\
\hline $\begin{array}{l}\text { Membranoproliferative } \\
\text { (MPGN) }\end{array}$ & $\begin{array}{l}3 \\
(1.10)\end{array}$ & $\begin{array}{l}2 \\
(66.67)\end{array}$ & $2(66.67)$ & $1(33.33)$ & 2 & 1 & $\begin{array}{l}51.33 \\
(44-65)\end{array}$ & 0.68 \\
\hline Anti GBM antibody disease & $\begin{array}{l}3 \\
(1.10)\end{array}$ & 0 & 0 & $3(100)$ & 3 & 0 & $\begin{array}{l}53.33 \\
(49-60)\end{array}$ & 0.11 \\
\hline Primary Amyloidosis & $\begin{array}{l}2 \\
(0.7) \\
\end{array}$ & 0 & $1(50)$ & $1(50)$ & 2 & 0 & $\begin{array}{l}64.5 \\
(54-75)\end{array}$ & 0.19 \\
\hline $\begin{array}{lll}\begin{array}{l}\text { Focal } \\
\text { (FPGN) }\end{array} & \text { proliferative } & \text { GN } \\
\end{array}$ & $\begin{array}{l}1 \\
(0.4)\end{array}$ & $\begin{array}{l}1 \\
(100) \\
\end{array}$ & 0 & $1(100)$ & 0 & 1 & 67 & 0.26 \\
\hline C3 Glomerulopathy (C3G) & $\begin{array}{l}1 \\
(0.4)\end{array}$ & 0 & 0 & 0 & 0 & 1 & 26 & 0.26 \\
\hline Total & $214(78.39)$ & 93 & 82 & 108 & 118 & 96 & $\begin{array}{l}40.28 \\
(12-80)\end{array}$ & \\
\hline
\end{tabular}

\begin{tabular}{|l|l|l|l|l|}
\hline \multicolumn{3}{|l|}{ Table 3: Histopathologic classification of IgA nephropathy as per Oxford classification } \\
\hline Grade & $\begin{array}{l}\text { Mesangial } \\
\text { hypercellularity }\end{array}$ & $\begin{array}{l}\text { Endocapillary } \\
\text { proliferation }\end{array}$ & $\begin{array}{l}\text { Segmental } \\
\text { sclerosis }\end{array}$ & Tubular atrophy \\
\hline 0 & 04 & 50 & 34 & 20 \\
\hline 1 & 58 & 12 & 28 & 27 \\
\hline 2 & NA & NA & NA & 15 \\
\hline
\end{tabular}


Figure 1: Ig A Nephropathy scoring as per Oxford classification

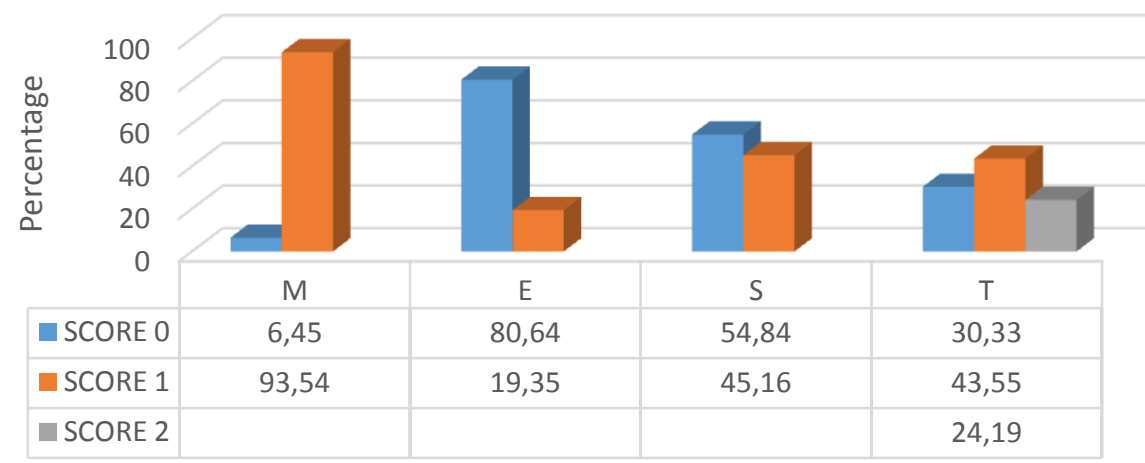

Scoring of parameters used in Oxford Classification

- SCORE $0 \quad$ SCORE 1 SCORE 2

\begin{tabular}{|c|c|c|c|c|c|c|c|c|}
\hline Renal disease & $\begin{array}{l}\text { Patients } \\
(\text { (n \& \%) }\end{array}$ & $\begin{array}{l}\text { HTN } \\
(\mathbf{n} \& \%)\end{array}$ & $\begin{array}{l}\text { Renal } \\
\text { failure } \\
(\mathbf{n} \& \%)\end{array}$ & $\begin{array}{l}\text { Nephrotic } \\
\text { syndrome } \\
(\text { (n \& \%) }\end{array}$ & $\begin{array}{l}\text { Males } \\
\text { (n) }\end{array}$ & $\begin{array}{l}\text { Females } \\
\text { (n) }\end{array}$ & $\begin{array}{l}\text { Age in years } \\
\text { (mean \& } \\
\text { range) }\end{array}$ & $\begin{array}{l}\text { p-value } \\
(\mathrm{M} \& \mathrm{~F})\end{array}$ \\
\hline $\begin{array}{l}\text { Diabetic nephropathy } \\
\text { (DN) }\end{array}$ & $15(5.49)$ & $7(46.67)$ & $6(40)$ & $8(53.33)$ & 10 & 5 & $52.2(30-65)$ & 0.001 \\
\hline Lupus nephritis (LN) & $14(5.13)$ & 0 & $2(14.28)$ & $6(42.86)$ & 0 & 14 & $26.14(11-39)$ & 0.007 \\
\hline $\begin{array}{l}\text { Hemolytic uremic } \\
\text { syndrome (HUS D-, } \\
\text { postpartum) }\end{array}$ & $1(0.4)$ & $1(100)$ & $1(100)$ & 0 & 0 & 1 & 36 & 0.48 \\
\hline $\begin{array}{l}\text { Alport's syndrome } \\
\text { (AS) }\end{array}$ & $1(0.4)$ & $1(100)$ & 0 & 0 & 0 & 1 & 16 & 0.48 \\
\hline $\begin{array}{l}\text { Membranoproliferati } \\
\text { ve (MPGN) }\end{array}$ & $1(0.4)$ & 0 & 0 & $1(100)$ & 0 & 1 & 72 & 0.48 \\
\hline $\begin{array}{l}\text { Membranous } \\
\text { nephropathy (MN) }\end{array}$ & $1(0.4)$ & 0 & 0 & $1(100)$ & 0 & 1 & 7 & 0.48 \\
\hline $\begin{array}{lr}\text { Light } & \text { chain } \\
\text { deposition } & \text { disease } \\
\text { (LCDD) } & \\
\end{array}$ & $1(0.4)$ & 0 & 0 & 0 & 1 & 0 & 49 & 0.14 \\
\hline Total & $\begin{array}{l}34 \\
(12.45)\end{array}$ & 9 & 9 & 16 & 11 & 23 & $36.90(11-72)$ & \\
\hline
\end{tabular}

\begin{tabular}{|c|c|c|c|c|c|c|c|c|}
\hline Renal disease & $\begin{array}{l}\text { Patients } \\
(n \& \%)\end{array}$ & $\begin{array}{l}\text { HTN } \\
(\text { n \& \%) }\end{array}$ & $\begin{array}{l}\text { Renal } \\
\text { failure } \\
(n \& \%)\end{array}$ & $\begin{array}{l}\text { Nephrotic } \\
\text { syndrome } \\
(\text { \& \& \%) }\end{array}$ & $\begin{array}{l}\text { Males } \\
\text { (n) }\end{array}$ & $\begin{array}{l}\text { Females } \\
\text { (n) }\end{array}$ & $\begin{array}{l}\text { Age in years } \\
\text { (mean \& } \\
\text { range) }\end{array}$ & $\begin{array}{l}\text { p-value } \\
(M \& \text { F })\end{array}$ \\
\hline $\begin{array}{l}\text { Acute tubular necrosis } \\
\text { (ATN) }\end{array}$ & $10(3.66)$ & $1(10)$ & $8(80)$ & 0 & 7 & 3 & $44.1(17-63)$ & 0.6 \\
\hline $\begin{array}{l}\text { Chronic Tubulointerstitial } \\
\text { nephritis (CTIN) }\end{array}$ & $7(2.56)$ & $4(57.14)$ & $7(100)$ & 0 & 4 & 3 & $48(40-60)$ & 0.65 \\
\hline Cast nephropathy $(\mathrm{CN})$ & $4(1.5)$ & $1(25)$ & $4(100)$ & 0 & 3 & 1 & $54(47-61)$ & 0.25 \\
\hline $\begin{array}{l}\text { Acute interstitial nephritis } \\
\text { (AIN) }\end{array}$ & $3(1.1)$ & 0 & $3(100)$ & 0 & 1 & 2 & $64.67(48-76)$ & 0.24 \\
\hline $\begin{array}{lll}\text { Acute } & \text { cortical } & \text { necrosis } \\
(\mathrm{ACN}) & & \end{array}$ & $1(0.4)$ & 0 & $1(100)$ & 0 & 1 & 0 & 40 & 0.44 \\
\hline Total & $25(9.16)$ & 6 & 25 & 0 & 16 & 9 & $50.15(17-76)$ & \\
\hline
\end{tabular}




\begin{tabular}{|l|l|l|l|l|l|}
\hline \multicolumn{2}{|l|}{ Table 6: Pattern of BPRD in patients DM; who underwent renal biopsy with suspicion of non-diabetic renal disease } \\
\hline Renal disease & $\begin{array}{l}\text { Patients: number } \\
\text { and percentage }\end{array}$ & Males & Females & $\begin{array}{l}\text { Age } \\
\text { mean) }\end{array}$ & $\begin{array}{l}\text { (range, } \\
\text { Duration of DM in } \\
\text { (range, mean) }\end{array}$ \\
\hline Diabetic nephropathy & $15(25.00)$ & 10 & 5 & $30-65,52.2$ & $10(3-16)$ \\
\hline $\begin{array}{l}\text { Diabetic nephropathy with } \\
\text { superimposed non-diabetic renal } \\
\text { disease }\end{array}$ & $10(16.67)$ & 9 & 1 & $27-65,51$ & $9.33(2-15)$ \\
\hline Non-diabetic renal disease & $35(58.33)$ & 20 & 15 & $23-80,53.62$ & $6.83(1-15)$ \\
\hline Total & 60 & 39 & 21 & $23-80,52.2$ & $7.94(1-16)$ \\
\hline
\end{tabular}

Figure 2: Histopathologic patten of BPRD in patients of DM who underwent biopsy with suspicion of nondiabetic renal disease

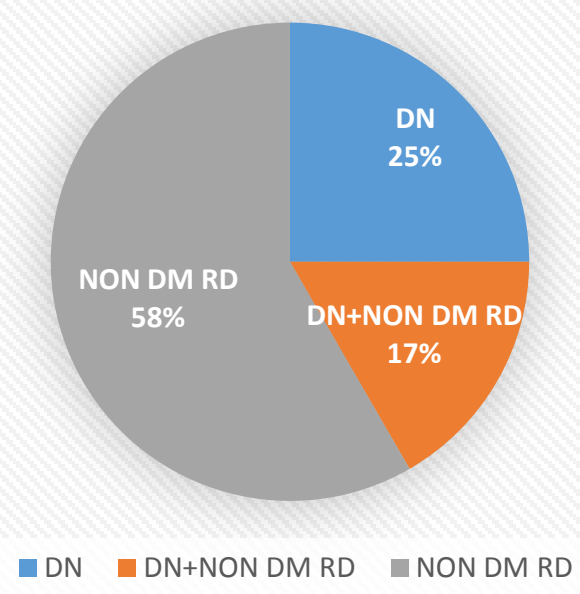

Figure 3: Histopathology of patients with DM

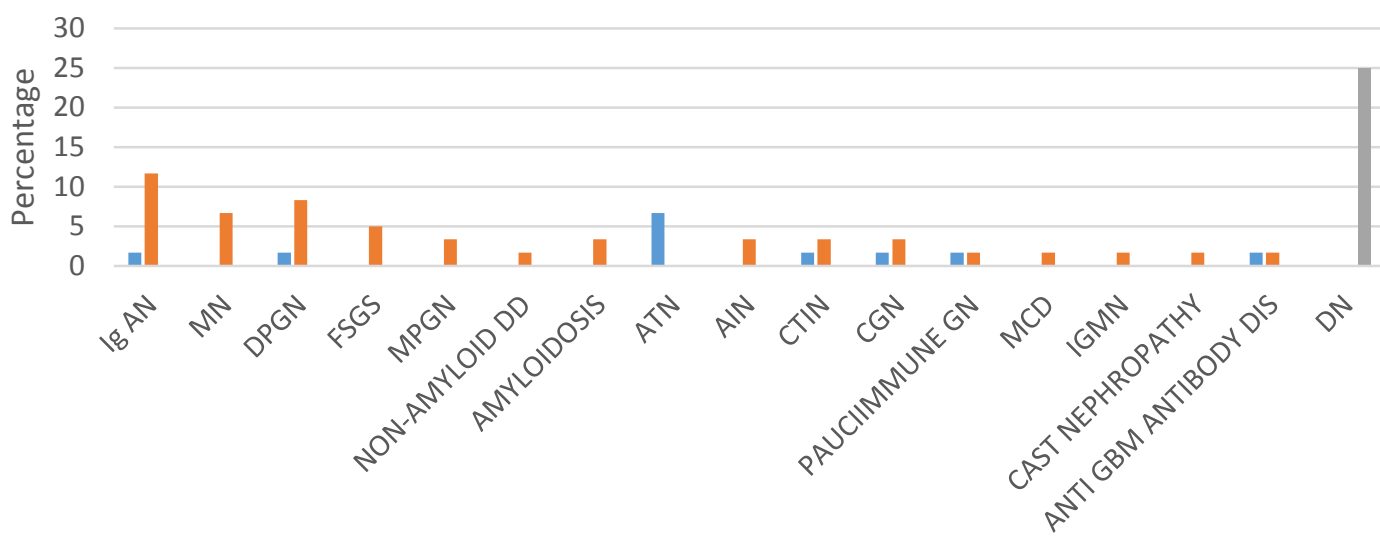

Histological diagnosis

- Superimposed renal disease in those with DN $\quad$ Non diabetic renal disease Diabetic nephropathy 


\section{DISCUSSION}

This retrospective study of 273 consecutive renal biopsies, illustrates the distribution of BPRD among patients at single centre. The PGD were the commonest $(78.39 \%)$ of BPRD; followed by SGD (12.45\%) and TID (9.16\%) similar to earlier reports from India. ${ }^{[2-8]}$

\section{Primary glomerular diseases (PGD)}

The Ig A nephropathywas the commonest PGD in present study is consistent with our previous report from AIMS, Kochi, Kerala. ${ }^{[2]}$ The MCD, Mesangioproliferative GN (non-IgAN), and MN were the commonest PGD in earlier reports. ${ }^{[3-8]}$ Variations in prevalence of PGD may be related to the demographic profile and period of study. ${ }^{[2-8]}$

The biopsies of patients with $\operatorname{IgAN}$ was classified according to the Oxford-MEST classification. Majority of the patients had mesangial hypercellularity (M1) (93.54\%), tubular atrophy (67.74\%; T1-43.55, T2-24.19). The segmental sclerosis (S1) was present in $45 \%$ and only few patients had endocapillary proliferation (E1) $(18.33 \%)$ and glomerular crescents (10\%). The most common type of IgAN as per Oxford-MEST classification in the study was M1, E0, S0, T1 (20.97\%) and the least common type was M0, E0, S0, T0 (4.84\%).

The observations of present study in IgAN (Oxford-MEST classification) are consistent earlier reports from India, which showed that patients of Indian subcontinent have aggressive disease type; unlike western literature. ${ }^{[9-11]}$ The mesangial hypercellularity (M1) was noted in $68.18 \%$, endocapillary proliferation (E1) was noted in $24.24 \%$, and segmental sclerosis (S1) in $48.48 \%$ and tubular atrophy in $74.23 \% \quad(\mathrm{~T} 1=1$ $30.30 \%$ and $\mathrm{T}=2$ in $43.93 \%)$. ${ }^{[9]} \mathrm{In}$ an Iranian study; the morphologic variables of MEST classification were; M1: $90.2 \%$, E1: $32 \%$, S1: 67 $\%, \mathrm{~T}$ in grades 1 and 2 were in $30 \%$ and $19 \%$ respectively, similar to present study. ${ }^{[10]}$ In a study from Brazil, segmental sclerosis (S1), mesangial hypercellularity (M1) and endocapillary proliferation (E1), tubular atrophy (T1 \& T2) were observed, in $47.6,42.2,13.7$ and $22.2 \%$ of the patients respectively. ${ }^{[11]}$ The reports using Hass classification for IgAN from India, also showed that the Indian patients suffer from an advanced disease. ${ }^{[9,12]}$

FSGS was the second commonest (13.55\%) PGD in present study consistent with earlier reports. [2$4,8]$ In majority of the patients with FSGS; it was NOS type $(94.59 \%)$ followed by tip $(2.7 \%)$ and perhilar variants $(2.7 \%)$.

FSGS, MN and MCD were the 3 most common causes for PGD causing nephrotic syndrome in our study, similar to earlier reports. ${ }^{[3,5,6,8,13-15]}$

\section{Secondary glomerular diseases (SGD)}

Diabetic nephropathy and LN were the two most common biopsy proven SGD, in our study, consistent with earlier reports. ${ }^{[2,4,6,8]}$ The amyloidosis, HUS/TTP, were the second commonest SGD, in other reports, unlike our study. ${ }^{[2,3,7]}$ Among the patients of DM who underwent renal biopsy with suspicion of NDRD; $25 \% \mathrm{DN} ; 16.67 \%$ had DN+NDRD and $58.33 \%$ had NDRD. Observations our study are consistent with earlier reports of BDRD in patients with DM. The prevalence rates of DN, NDRD+ND and NDRD were $6.5,10.7$ and $82.9 \%$ respectively in one study and $21.18,40$ and $38.82 \%$ of patients, respectively in another study. ${ }^{[16,17]}$ Two studies from India also showed that the NDRD were 25$64 \%$ of patients of DM, similar to present study. [18, 19] The mean duration of diabetes mellitus was lower in patients with NDRD than DN or DN+NDRD. The four most common NDRD were Ig AN followed by DPGN, MN, FSGS, TID in present study. The commonest NDRD were IgAN, MN and TID in one study and TID and glomerulopathies in another study. ${ }^{[16,17]}$ The common NDRD in Indian studies were MCD, TID and Lupus nephritis. ${ }^{[19]}$

\section{Tubulointerstitial diseases (TID)}

TID were the least frequent of the BPRD, in our study, consistent with earlier reports. [2,4-8]ATN was themost common, biopsy proven TID followed by, CTIN, Cast nephropathy, AIN and ACN. 


\section{CONCLUSIONS}

The prevalence rates of PGD, SGD and TID in this study were78.39, 12.45 and $9.16 \%$ respectively. The Ig A nephropathywas the commonest PGD in present study is consistent with our previous report from AIMS, Kochi, Kerala. Variations in prevalence of PGD may be related to the demographic profile and period of study.Majority of the patients of IgAN had mesangial hypercellularity (M1) tubular atrophy (T1 or T2) with most common pattern being M1, E0, S0, T1, suggesting that patients of Indian subcontinent have aggressive disease type; unlike western literature. FSGS was the second commonest PGD in present study consistent with majority being it was NOS type. FSGS, MN and MCD were the 3 most common causes for PGD causing nephrotic syndrome.

Diabetic nephropathy and LN were the two most common biopsy proven SGD. Among the patients of DM who underwent renal biopsy with suspicion of NDRD; $25 \%$ DN; $16.67 \%$ had DN+NDRD and $58.33 \%$ had NDRD. The mean duration of diabetes mellitus was lower in patients with NDRD than DN or DN+NDRD. The four most common NDRD in patients with DM were Ig AN followed by DPGN, MN, FSGS, TID.

ATN was themost common, biopsy proven TID followed by, CTIN, Cast nephropathy, AIN and ACN.

\section{REFERENCES}

1. Prasad N, Kumar S, Manjunath R, Bhadauria D, Kaul A, Sharma RK, et al. Real-time ultrasound-guided percutaneous renal biopsy with needle guide by nephrologists decreases post-biopsy complications.Clin Kidney J. 2015;8(2):151-156. DOI: 10.1093/ckj/sfv012.

2. Srija M, Lakshminarayana G, Anil M, Rajesh R, Kurian G, Unni VN. Pattern of renal diseases on kidney biopsies at a tertiary care hospital in Kerala. Amrita Journal of Medicine 2011; 7 (1): 32-39.
3. Ramesh CV, Ravi KM, Prasad G. Spectrum of biopsy proven renal disease referral hospital experience in a developing nation: Analysis based on 624 renal biopsies. International Journal of Science and Research (IJSR) 2014; 4 (4): 704-708.

4. Narasimhan B, Chacko B, John GT, Korula A, Kirubakaran MG, Jacob CK. Characterization of kidney lesions in Indian adults: towards a renal biopsy registry.J Nephrol. 2006 MarApr;19(2):205-210.

5. Jayakumar J, Sushanth K, Mohammed K, Chakrapani M. Pattern of glomerular diseases in a tertiary care center in south India: A prospective study. Saudi J Kidney Dis Transpl 2013;24(1):168-171.

6. Clement WD, Vijaya MV Gireesh MS, Mahesh E, Gurudev KC, Radhika K. Review of renal biopsy database: a single centre south Indian study.Int J Med Res Health Sci.2014;3(4):959-966.

7. Sunita S, Nisha M, Rajeev S, Monika S, Renuka V, Megha R. Profile of renal biopsies in a tertiary care hospital. International J. of Healthcare and Biomedical Research 2014; 2 (3): 53-59.

8. Das U, Dakshinamurty KV, Prayaga A. Pattern of biopsy-proven renal disease in a single center of south India: 19 years' experience. Indian J Nephrol 2011; 21:250-257.

9. Neha M, Kusum J, Swapnil R, Ritambhra $\mathrm{N}$, Vinay S.Primary IgA nephropathy in north India: is it different? Postgrad Med J 2011;88 (1035): 1520.DOI:10.1136/postgradmedj-2011130077.

10. Hamid N, Mojgan M, Ali G, Heshmatollah S, Soleiman K, Azar B, et al. OxfordMEST classification in $\operatorname{IgA}$ nephropathy patients: A report from Iran. J Nephropathology. 2012; 1(1):31-42. DOI: 10.5812/jnp.7. 
11. Maria FS, Caldas MLR, Dos-Santos WLC, Sementilli A, Furtado P, Araújo S, Pegas KL, Petterle RR, and Franco MF. IgA nephropathy in Brazil: apropos of 600 cases.SpringerPlus 2015; 4:547. DOI 10.1186/s40064-015-1323-x.

12. Vanikar AV, Kanodia KV, Patel RD, Trivedi HL.Primary Immunoglobulin A (IgA) nephropathyin Western India. Indian J Nephrol 2005;15: 227-231.

13. Sanjay D, Satyam SJ, Rakesh G. Original Article - Study of Etiological Profile of Nephrotic Syndrome in Adults. International Journal of Applied Research 2015; 1(9): 545-549.

14. Vishal G, Mayuri T, Anila AK, Dipankar S, Arpita R, Rajendra P.Spectrum of nephrotic syndrome in adults: Clinicopathological study from a single center in India. Renal Failure 2013; 35 (4): 487-491.

DOI: 10.3109/0886022X.2013.768939.

15. Deepa G, Vikas C. Clinicopathological study of nephrotic syndrome in adults. Journal of Evidence Based Medicine and Healthcare 2015; 2 (49): 8518-8520, DOI: 10.18410/jebmh/2015/1168.

16. Li Z, Wenwen R, Wenge L, Guming Z, Jianhua L. Evaluation of renal biopsies in type 2 diabetic patients with kidney disease: A clinicopathological study of 216 cases. International Urology and Nephrology 2013; 45 (1): 173-179.

17. Chien-Pin L, Chia-Chu C, Yu Y, Yau-Ko W, Pin-Fang C, Mei-ling C, Kun-Tu Y, Yet-Ming L.Non-diabetic renal diseases in type 2 diabetic patientswith renal involvement: Clinicopathological study in asingle medical center in Taiwan. ActaNephrologica 2010; 24: 157-166.

18. Prakash J. Non-diabetic renal disease (NDRD) in patients with type 2 diabetes mellitus (Type 2 DM).J Assoc Physicians India. 2013;61(3):194-199.

19. Das U, Dakshinamurty KV, Prayaga V, Uppin MS. Nondiabetic kidney disease in type 2 diabetic patients: A single center experience. Indian J Nephrol. 2012; 22(5): 358-362.

DOI: 10.4103/09714065.103912 . 